\title{
Genetic Diversity of Accessions and First Generation Progeny of the Mangaba Genebank
}

\author{
Adrielle Naiana Ribeiro Soares ${ }^{1}$, Debora Clivati2 ${ }^{2}$ Marília Freitas de Vasconcelos Melo3, \\ Matthew Gitzendanner ${ }^{4}$, Pamela Soltis ${ }^{4}$, Douglas Soltis, Josué Francisco da Silva Júnior ${ }^{5}$, \\ Ana da Silva Ledo 5 , Ana Veruska Cruz da Silva ${ }^{5}$
}

${ }^{1}$ Federal University of Sergipe, São Cristovão, Brazil

${ }^{2}$ National Institute of Amazonian Research, Manaus, Brazil

${ }^{3}$ Federal University of Alagoas, Maceió, Brazil

${ }^{4}$ University of Florida, Gainesville, USA

${ }^{5}$ Embrapa Coastal Tablelands, Aracaju, Brazil

Email: ana.veruska@embrapa.br

How to cite this paper: Soares, A.N.R., Clivati, D., de Vasconcelos Melo, M.F., Gitzendanner, M., Soltis, P., Soltis, D., da Silva Júnior, J.F., da Silva Ledo, A. and da Silva, A.V.C. (2018) Genetic Diversity of Accessions and First Generation Progeny of the Mangaba Genebank. American Journal of Plant Sciences, 9, 1618-1629.

https://doi.org/10.4236/ajps.2018.98117

Received: March 28, 2018

Accepted: July 7, 2018

Published: July 10, 2018

Copyright $(9) 2018$ by authors and Scientific Research Publishing Inc. This work is licensed under the Creative Commons Attribution-NonCommercial International License (CC BY-NC 4.0). http://creativecommons.org/licenses/by-nc/4.0/ (c) (i) \& Open Access

\begin{abstract}
Mangaba (Hancornia speciosa Gomes-Apocynaceae) is an important fruit tree in Brazil and has an unexplored stock germplasm collection. Commercial varieties are unavailable and little is known about its potential as a source of genetic diversity for molecular breeding programs. Progeny tests may improve studies on commercial variability and facilitate genetic improvement of the species. Our aim was to evaluate the genetic diversity and structure of accessions and progeny from the Mangaba Genebank of Embrapa Coastal Tablelands. We estimated the genetic diversity of 96 individuals using 4 SSR markers. The mean observed heterozygosity was lower than expected, showing an excess of homozygotes, corroborated by the positive coefficient of endogamy. The genetic diversity indexes $\left(F_{s t}\right)$ and Nei's unbiased genetic identity (GI) revealed, in general, moderate genetic diversity between accessions. The relationship between matrices and progenies showed that there may be a greater degree of genetic information sharing between the $\mathrm{ABP} 1$ and $\mathrm{ABP} 2$ accessions. The Bayesian analysis suggested the presence of two distinct groups of genotypes $(K=2)$. These results will assist future breeding programs and facilitate the conservation of mangaba.
\end{abstract}

\section{Keywords}

Hancornia speciosa Gomes, Brazilian Fruits, Microsatellite Markers, Genetic Resources 


\section{Introduction}

The mangaba tree (Hancornia speciosa Gomes-Apocynaceae) is a Brazilian native, occurring in various habitats, including the Cerrado and the "restingas" of the Atlantic Forest, where it is of economic, social and cultural importance [1]. The fruit is used in ice creams, fruit pulp concentrates, jams, jellies and spirits [2]. The bark is also used in folk medicine and latex production [3]. Despite the increasing agro-industrial importance of the mangaba, extractivism still presents itself as the main form of mangaba exploitation.

The exploitation of mangaba fruits, as well as the fragmentation of the natural habitat of the species, decreased population size, compromising the next generation by means of natural regeneration mechanisms. This condition, over time, can decrease the genetic variability in natural populations, developing less vigorous individuals, possibly lacking important economic characters [4].

The use of ex situ strategies, as in Genebanks, is fundamental for the conservation of genetic diversity of the mangaba tree. Considering that much of the large natural range of mangaba is already devastated, the Brazilian Agricultural Research Corporation/Embrapa, sub-agency Embrapa Coastal Tablelands, has maintained an active germplasm collection since 2006. The first step to identify duplicates and parents is characterizing the genetic diversity of collections and germplasm banks, which will help in the production of hybrids with greater commercial potential [5] and a way of reconciling agrobiodiversity conservation efforts with sustainable development.

Research on the mangaba tree is recent, especially the studies of genetic diversity using different molecular markers, such as RAPD [1] [2], ISSR [6] [7] [8] [9] and SSR [10]. These studies are important to assist in the knowledge of the genetic diversity of native populations and accessions, and can be used as tools to design conservation strategies and collection of new accessions to be introduced into the germplasm bank. Despite the existing studies with Mangaba genebank, this was the first work with progeny evaluation, aiming to broaden the knowledge of the genetic material present in the bank, thus, the study of progeny is essential so that in the future it is possible to identify and select the best parents to be used in breeding programs. One of the best ways to assess genetic diversity is using molecular tools to evaluate whether the genetic diversity within selected individuals is adequate to constitute cultivated varieties in breeding programs. Therefore, it is fundamental to understand genetic variability, especially of poorly studied native species, whose diversity remains almost unknown [2], such as the mangaba tree [11].

For genetic diversity studies, microsatellite markers (SSR) are suitable tools due to their codominant nature, the capability of detecting high rates of polymorphism, and their high reproducibility [12]. These markers have already been characterized and tested in natural mangaba tree populations from Brazilian Northeast [10] [13].

Our aim was to estimate the genetic diversity of the accessions and first progenies from the Mangaba Genebank, using microsatellite markers. 


\section{Material and Methods}

The Mangaba Genebank (Figure 1) occupies a restinga area, in the municipality of Itaporanga d'Ajuda, state of Sergipe, Brazil ( $11^{\circ} 06^{\prime} 40^{\prime \prime S}$ e $\left.37^{\circ} 11^{\prime} 15^{\prime \prime W}\right)$. The first fruiting occurred in 2013 [14] and following the second harvest in 2014, the fruits were collected, and their seeds were used to generate the first progeny arrays.

Fruits were harvested (Figure 2(a), Figure 2(b)), smimmed and seeds were treated (soaked in a $2.5 \%$ sodium hypochlorite solution for 3 minutes), then washed in distilled water, and then dried in the shade, at $25^{\circ} \mathrm{C}$; after 24 hours the seeds were sown in polyethylene bags filled with sand, and grown in a greenhouse (Figure 2(c), Figure 2(d)).

After six months of growth, leaves of each progeny were collected for molecular analysis. The number of progeny per accession varied from 7 to 10 , for a total of 96 individuals, of which 87 are progeny from 9 accessions (Table 1).

Total genomic DNA was isolated from $-80^{\circ} \mathrm{C}$ frozen leaf tissue following the cetyltrimethylammonium bromide (CTAB) protocol [15] as modified by [16]. Extracted DNA was eluted in $50 \mu \mathrm{L}$ of TE and directly amplified, using 16 primer pairs [17].

PCR reactions were performed in $10 \mu \mathrm{L}$ total volume; the reaction mix contained $1.0 \mu \mathrm{L}$ of genomic DNA, 1.0 $\mu \mathrm{L}$ of $10 \times$ Taq PCR buffer, $0.8 \mu \mathrm{L}$ of $\mathrm{MgCl}_{2}$ ( $25 \mathrm{mM}), 0.2 \mu \mathrm{L}$ of dNTP (2.5 mM mix), $1.0 \mu \mathrm{L}$ of each primer $(5 \mathrm{mM}$, forward 6-FAM and reverse-HEX) and $0.1 \mathrm{U}$ Taq polymerase and $4.9 \mu \mathrm{L}$ of ultrapure water. Thermal cycling conditions were $94^{\circ} \mathrm{C}$ for $1 \mathrm{~min}$; 35 cycles of $95^{\circ} \mathrm{C}$ for 1 min, annealing temperature specific for each locus (Table 2) for $1 \mathrm{~min}$, and $72^{\circ} \mathrm{C}$ for $1 \mathrm{~min}$. PCR products generated from a total of 87 samples of mangaba accessions/progenies were genotyped on a 3730 ABI Genetic Analyzer (Applied Biosystems, Carlsbad, California, USA) at the Interdisciplinary Center of

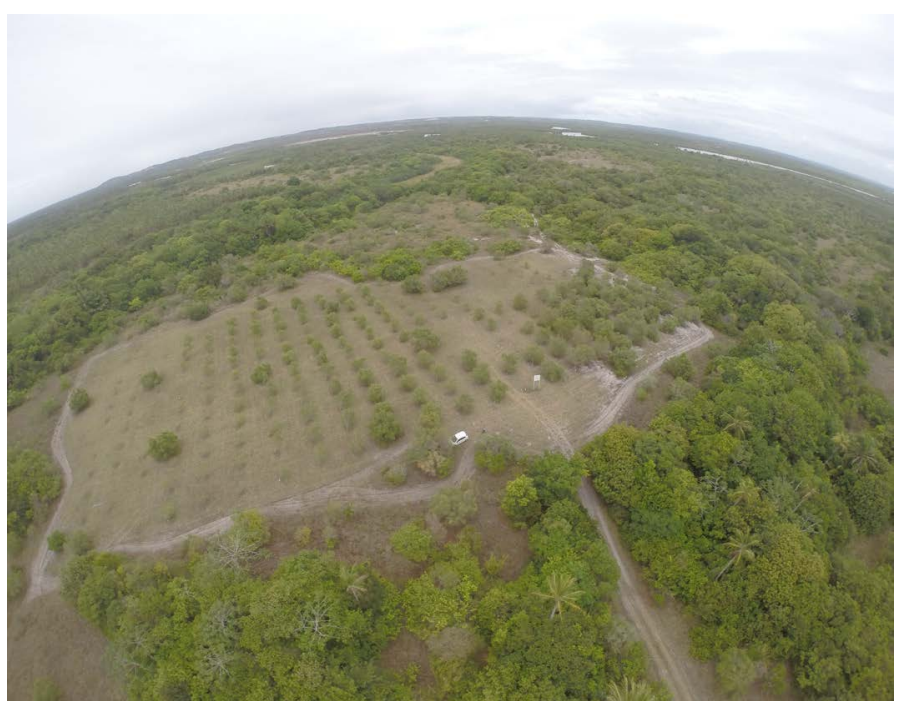

Figure 1. Aerial view of mangaba Genebank of Embrapa coastal tablelands. Itaporanga d'Ajuda, Sergipe, Brazil. 


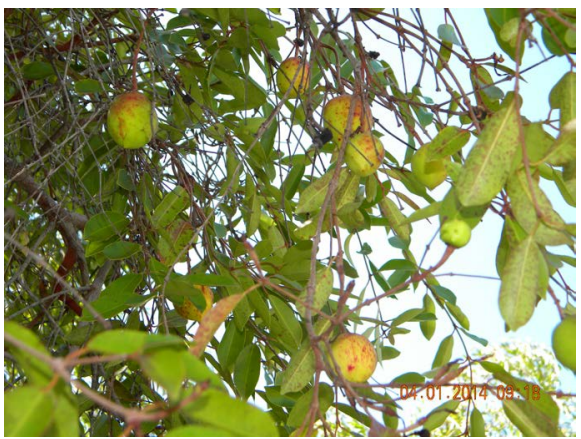

(a)

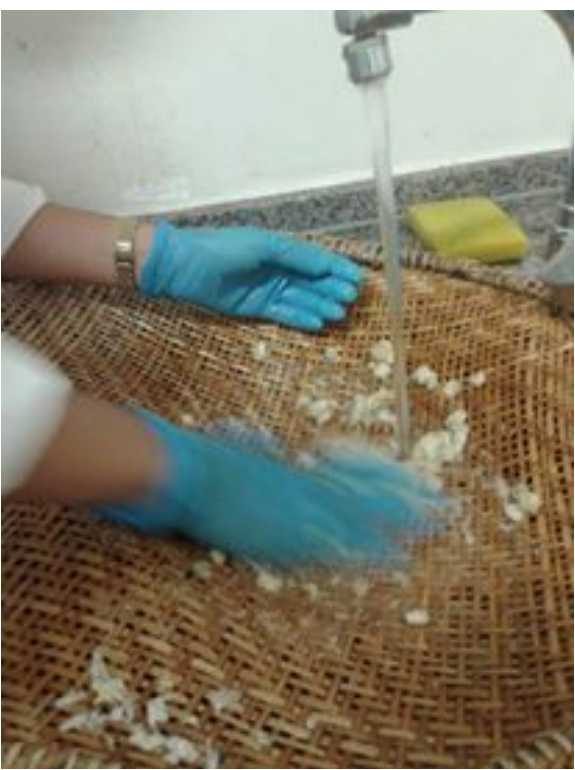

(c)

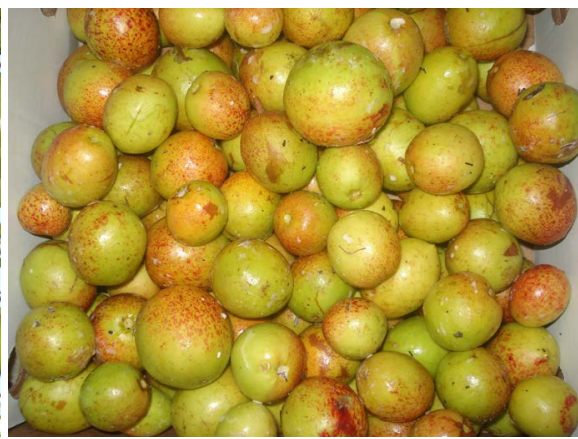

(b)

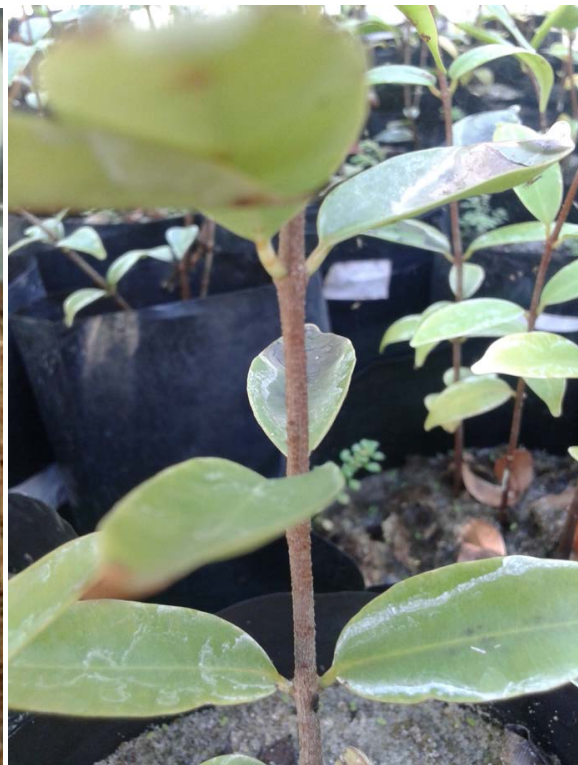

(d)

Figure 2. Mangaba fruits in tree (a), harvested (b), skimmed (c) and progeny (d).

Table 1. Accession codes, localities of origin of each accession of the Active Germplasm Bank of Mangaba, Embrapa Coastal Tablelands (BAGMangaba) used in this study.

\begin{tabular}{cc}
\hline Accessions & Origem \\
\hline ABP1 & Salvaterra, Pará \\
ABP2 & Salvaterra, Pará \\
BIP2 & Conde, Bahia \\
BIP4 & Conde, Bahia \\
CAP5 & Jandaíra, Bahia \\
LGP3 & Mata de São João, Bahia \\
PTP4 & Indiaroba, Sergipe \\
TCP2 & Indiaroba, Sergipe \\
TCP6 & Indiaroba, Sergipe \\
\hline
\end{tabular}

Biotechnology Research facility at the University of Florida. Peaks were scored using GeneMarker 1.6 (SoftGenetix, State College, Pennsylvania, USA), with manual corrections as needed. 
Table 2. Annealing temperature (Ta), repeat motifs, product size range in base pairs (bp), and primer fluorescence tested for genotyping of mangaba. In bold, the selected primers for genotyping. The product size was established by Rodrigues et al. (2015).

\begin{tabular}{ccccc}
\hline Primers & $\mathrm{Ta}\left({ }^{\circ} \mathrm{C}\right)$ & Repeat motif & Product size range & Fluorescence \\
\hline HS01 & 56 & $(\mathrm{GCA})_{6}(\mathrm{TC})_{20}(\mathrm{GCA})_{8}$ & $250-310$ & HEX \\
HS05 & 56 & $(\mathrm{GA})_{15}(\mathrm{TGC})_{6}$ & $200-300$ & HEX \\
HS06 & 54 & $(\mathrm{GA})_{14}$ & $\mathbf{1 0 0}-\mathbf{1 5 0}$ & HEX \\
HS09 & 56 & $(\mathrm{CT})_{7}(\mathrm{CT})_{10}(\mathrm{CT})_{6}$ & $\mathbf{2 0 0 - 3 0 0}$ & 6-FAM \\
HS03 & 56 & $(\mathrm{CT})_{5}(\mathrm{CT})_{5}$ & $120-180$ & 6-FAM \\
HS08 & 52 & $(\mathrm{CA})_{6}(\mathrm{CT})_{17}$ & $200-250$ & 6-FAM \\
HS10 & 56 & $(\mathrm{CT})_{14}(\mathrm{CT})_{8}$ & $100-200$ & HEX \\
HS11 & 56 & $(\mathrm{GA})_{17}$ & $100-200$ & 6-FAM \\
HS16 & 54 & $(\mathrm{GA})_{12}$ & $100-150$ & 6-FAM \\
HS17 & 56 & $(\mathrm{GA})_{16}$ & $100-200$ & HEX \\
HS18 & 56 & $(\mathrm{AG})_{14}$ & $300-350$ & 6-FAM \\
HS20 & 56 & $(\mathrm{CT})_{11}$ & $200-250$ & HEX \\
HS27 & 54 & $(\mathrm{GA})_{14}$ & $100-150$ & 6-FAM \\
HS30 & 56 & $(\mathrm{AG})_{10}$ & $180-200$ & HEX \\
HS32 & 56 & $(\mathrm{CT})_{9}$ & $200-300$ & 6-FAM \\
HS33 & 56 & $(\mathrm{AG})_{24}$ & $80-120$ & 6-FAM \\
\hline
\end{tabular}

We assessed the genetic diversity of mangaba progeny computing: 1) the observed number of alleles per locus $(\mathrm{Na})$ and mean $(\mathrm{A}) ; 2)$ the allele richness $(R)$ and mean; 3$)$ observed $\left(H_{o}\right)$ and expected heterozygosity $\left(H_{e}\right)$, calculated following Hardy-Weinberg proportions. A rarefaction method [18], as modified by [19], was applied to correct the observed number of alleles according to the sample size. Endogamy was surveyed with the fixation index $(F)$, and the statistical significance was tested using 1000 Monte Carlo permutations of alleles between individuals. All the analyses were calculated using FSTAT software version 2.9.3.2 [20].

Because each progeny plant received at least one maternal allele, the fixation index $(F)$ was estimated using $F=1-\left(H_{d} / H_{e}\right)$ [21]. Genetic divergence (Fst) and Nei genetic identity (GI) matrices were obtained using Genalex software version 6.3 [22]. The relationship between progenies and accessions was evaluated using the pedigreemm package [23] implemented in $\mathrm{R}$ [24].

The genetic diversity was associated with the geographic origin of the accessions using a Bayesian clustering approach implemented in the Structure software [25], which also was used to evaluate possible barriers to genetic flow.

\section{Results and Discussion}

Of the 16 microsatellite markers, 4 (HS01, HS05, HS06 and HS10) were found to 
be polymorphic throughout the accessions. The results for the number of alleles (A), allele richness (R), expected heterozygosity $\left(H_{\mathrm{e}}\right)$, observed heterozygosity $\left(H_{\mathrm{o}}\right)$ and inbreeding coefficient $(\mathrm{f})$ are represented in Table 3.

The number of alleles (A) ranged from 7 to 9.3. The number of alleles (A) in mangaba accessions was higher than reported for Acca selowiana 3.5 (range 2.9 4.1), when using microsatellites in natural populations [26].

The allele richness $(\mathrm{R})$ results revealed that progenies with the highest allele number also have the richest allele indexes. The distribution of allelic frequency and richness may decrease genetic variability, influence the presence of heterozygotes, and determine conservation program decisions [13].

In all progeny, the mean expected heterozygosity $\left(H_{\mathrm{e}}\right)$ was higher than the observed heterozygosity $\left(H_{\mathrm{o}}\right)$, suggesting a homozygote excess, as expected for populations in Hardy-Weinberg Equilibrium. In a study with $H$. speciosa, the microsatellite genotyping revealed higher values of $H_{o}$ (0.51 - 0.64 among populations) compared with $H_{\mathrm{e}}(0.30-0.42)$ [27]. Although the results differ from our results, it is noticed that the averages for heterozygosity were within the determined standard for the mangaba $-H_{\mathrm{o}}(0.698)$ lower than $H_{\mathrm{e}}(0.750)$ [28].

All progeny showed positive mean inbreeding coefficient $(f)$, confirming the excess of homozygotes. The highest $f$ was observed in progenies from accessions $\mathrm{ABP} 1, \mathrm{BIP} 4$ and CAP5, and the lowest in progenies from PTP4 (0.08), TCP6 (0.08), ABP2 (0.06) and BIP2 (0.09). Overall, the positive inbreeding coefficient reveals an excess of homozygotes, and fewer observed heterozygotes than expected, according to the Hardy-Weinberg Equilibrium. Furthermore, the inbreeding coefficient allows detecting deficiency or excess of heterozygotes in the populations. Our results suggest an inbreeding effect in the evaluated progenies, based on the homozygote excess.

Inbreeding was also evidenced in populations of goiabeira-serrana (Acca sellowiana) [26] and camu-camu (Myrciaria dubia [HBK] McVaugh) [29], and like mangaba tree, they are allogamous species, indicating that it is common to find positive inbreeding coefficients in tropical tree species.

Indexes of genetic divergence in most breedings between accessions showed moderate diversity $-0.05-0.15$, according to [30]-except for those originated from parental ABP1 × BIP4; ABP1 × TCP6; ABP2 × BIP4; ABP2 × CAP5; ABP2 $\times$ LGP3; ABP $2 \times$ PTP4; ABP $2 \times$ TCP2 and ABP2 $\times$ TCP6 (range $0.280-0.599$ ). Progenies originated from PTP $4 \times$ TCP2, PTP $4 \times$ TCP 6 and TCP $2 \times$ TCP 6 showed lowest Fst values (Table 4).

The genetically most divergent accessions, $\mathrm{ABP} 1$ and $\mathrm{ABP} 2$, are also the most geographically distant populations, from the state of Pará. Similarly, the accessions PTP4, TCP2 and TCP6, from the state of Sergipe, are more genetically related with each other. Genetically related accessions from geographically close areas may be due to a possible genetic flow in natural mangaba tree populations, in accordance with [10]. The genetic composition of a species and its structure in original populations is fundamental for management and conservation actions. However, it is necessary to understand if the observed genetic structure is 
Table 3. Number of samples (n), number of alleles (A), allele richness (R), expected heterozigosity $(\mathrm{He})$, observed heterozygosity $(\mathrm{Ho})$, endogamy coefficient $(\mathrm{F})$ of the 4 evaluated microsatellite loci from all progenies derived from nine accessions of Mangaba Genebank of Embrapa Coastal Tablelands.

\begin{tabular}{ccccccc}
\hline Accessions & $\mathbf{n}$ & $\mathbf{A}$ & $\mathbf{R}$ & He & Ho & $\mathbf{F}$ \\
\hline LGP3 & 10 & 7.0 & 5.48 & 0.83 & 0.60 & 0.14 \\
PTP4 & 10 & 9.0 & 6.49 & 0.87 & 0.50 & 0.08 \\
TCP2 & 10 & 7.6 & 5.12 & 0.78 & 0.48 & 0.24 \\
TCP6 & 7 & 7.0 & 6.43 & 0.91 & 0.43 & 0.08 \\
ABP1 & 10 & 9.0 & 6.52 & 0.92 & 0.70 & 0.51 \\
ABP2 & 10 & 7.0 & 6.11 & 0.85 & 0.40 & 0.06 \\
BIP2 & 10 & 9.0 & 6.66 & 0.90 & 0.30 & 0.09 \\
BIP4 & 10 & 9.3 & 6.77 & 0.91 & 0.50 & 0.39 \\
CAP5 & 10 & 7.3 & 6.13 & 0.90 & 0.70 & 0.28 \\
Mean & & 8.0 & 6.10 & 0.87 & 0.51 & 0.21 \\
\hline
\end{tabular}

Table 4. Divergence array correlating Fst (genetic divergence index, below diagonal) between progenies of Mangaba Genebank of Embrapa Coastal Tablelands.

\begin{tabular}{cccccccccc}
\hline ABP1 & ABP2 & BIP2 & BIP4 & CAP5 & LGP3 & PTP4 & TCP2 & TCP6 & \\
\hline 0.000 & & & & & & & & & ABP1 \\
0.065 & 0.000 & & & & & & & & ABP2 \\
0.051 & 0.056 & 0.000 & & & & & & & BIP2 \\
0.280 & 0.330 & 0.057 & 0.000 & & & & & & BIP4 \\
0.174 & 0.400 & 0.130 & 0.128 & 0.000 & & & & & CAP5 \\
0.089 & 0.406 & 0.098 & 0.130 & 0.120 & 0.000 & & & & LGP3 \\
0.074 & 0.413 & 0.140 & 0.084 & 0.109 & 0.071 & 0.000 & & & PTP4 \\
0.123 & 0.507 & 0.077 & 0.057 & 0.110 & 0.055 & 0.042 & 0.000 & & TCP2 \\
0.563 & 0.599 & 0.057 & 0.069 & 0.050 & 0.079 & 0.036 & 0.023 & 0.000 & TCP6 \\
\hline
\end{tabular}

intrinsic to the species or if it is the result of physical-anthropic barriers, such as habitat fragmentation.

The genetic identity matrix of Nei (GI) (Table 5) revealed that the progenies of the accesses CAP5, LGP3 (state of Bahia), PTP4, TCP2 and TCP6 (Sergipe state) were more similar to each other, with similarity values varying between 0.521 to 0.95 of divergence. Mangaba populations of Pernambuco and Alagoas in the Brazilian Northeast showed high similarity based on Nei's genetic identity matrix (Table 5), with values varying between 0.99 and 0.93 [27].

The relationship between progenies and matrices (Table 6) showed that there may be a greater sharing of genetic material among all progenies of ABP1 access (0.50), followed by ABP2 accessions (0.25). The progenies from CAP5 access, for the most part, obtained lower values. 
Table 5. Nei's genetix identity matrix (GI) between progenies from accessions of Mangaba Genebank of Embrapa Coastal Tablelands. Obtained by Nei genetic distance (Nei, 1977).

\begin{tabular}{cccccccccc}
\hline ABP1 & APB2 & BIP2 & BIP4 & CAP5 & LGP3 & PTP4 & TCP2 & TCP6 & \\
\hline 1.000 & & & & & & & & & ABP1 \\
0.398 & 1.000 & & & & & & & APB2 \\
0.108 & 0.141 & 1.000 & & & & & & BIP2 \\
0.125 & 0.266 & 0.227 & 1.000 & & & & & BIP4 \\
0.072 & 0.324 & 0.256 & 0.629 & 1.000 & & & & CAP5 \\
0.087 & 0.154 & 0.167 & 0.244 & 0.876 & 1.000 & & & LGP3 \\
0.284 & 0.138 & 0.184 & 0.209 & 0.939 & 0.945 & 1.000 & & & PTP4 \\
0.230 & 0.126 & 0.130 & 0.152 & 0.521 & 0.678 & 0.900 & 1.000 & & TCP2 \\
0.127 & 0.158 & 0.078 & 0.070 & 0.098 & 0.789 & 0.840 & 0.950 & 1.000 & TCP6 \\
\hline
\end{tabular}

Table 6. Relationship between matrices and progeny from accessions of the Mangaba Genebank of Embrapa Coastal Tablelands.

\begin{tabular}{ccccccccccc}
\hline \multicolumn{7}{c}{ Progenies } \\
\hline Matrices & 1 & 2 & 3 & 4 & 5 & 6 & 7 & 8 & 9 & 10 \\
\hline ABP1 & 0.500 & 0.500 & 0.500 & 0.500 & 0.500 & 0.500 & 0.500 & 0.500 & 0.500 & 0.500 \\
ABP2 & 0.250 & 0.250 & 0.250 & 0.250 & 0.250 & 0.250 & 0.250 & 0.250 & 0.250 & 0.250 \\
BIP2 & 0.230 & 0.250 & 0.250 & 0.250 & 0.250 & 0.250 & 0.250 & 0.250 & 0.250 & 0.250 \\
BIP4 & 0.230 & 0.230 & 0.230 & 0.250 & 0.250 & 0.250 & 0.250 & 0.250 & 0.250 & 0.250 \\
CAP5 & 0.230 & 0.230 & 0.230 & 0.230 & 0.230 & 0.230 & 0.230 & 0.125 & 0.250 & 0.250 \\
LGP3 & 0.250 & 0.250 & 0.250 & 0.250 & 0.250 & 0.250 & 0.250 & 0.230 & 0.230 & 0.230 \\
PTP4 & 0.250 & 0.250 & 0.250 & 0.250 & 0.250 & 0.250 & 0.125 & 0.230 & 0.230 & 0.230 \\
TCP2 & 0.250 & 0.250 & 0.250 & 0.250 & 0.250 & 0.250 & 0.250 & 0.230 & 0.230 & 0.230 \\
TCP6 & 0.250 & 0.250 & 0.250 & 0.250 & 0.250 & 0.250 & 0.230 & & & \\
\hline
\end{tabular}

The reproductive system of the mangaba tree is allogamous. The choice of the parents can influence the discovery and use of genes responsible for characteristics of agronomic interest and genetic divergence, allowing a breeder to obtain superior plants. Thus, the genetic study of progeny is a breakthrough that provides information to more accurately select the parents and to better plan crossings.

Based on the Bayesian analysis of clusters, the progeny formed two distinct genetic groups $(k=2)$ (Figure 3 ). The progenies of the PTP4 and TCP2 (Sergipe) accessions were more homogeneous and similar to each other (greater predominance of red bars). The natural accessions of Pará (ABP1 and ABP2) were also homogeneous (predominance of green bars). The others, although close, were heterogeneous, and presented mixed (red and green bars). 


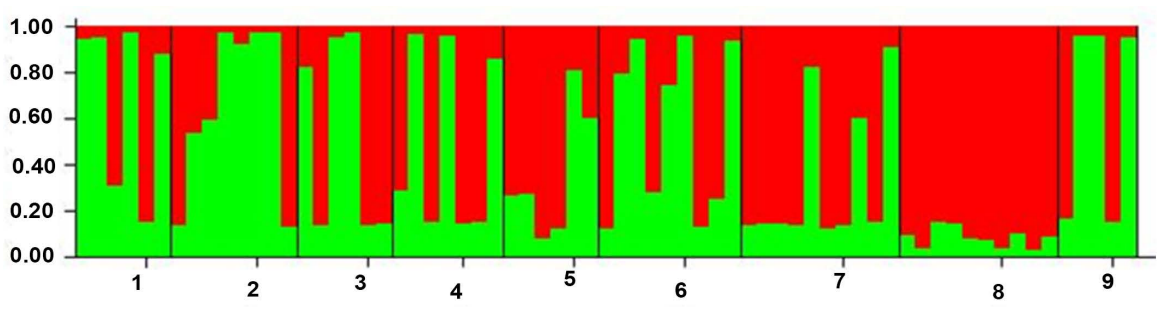

Figure 3. Bar plot estimated by Structure depicting group membership (hybrid ancestry). Each accession is represented by a bar, which is partitioned into $K=2$ colored components, indicating the accession's estimated membership coefficients in the $K$ clusters (y axis). Numbers (x axis) represent geographic origin of accessions 1. ABP1 (Pará); 2. ABP2 (Pará); 3. BIP2 (Bahia); 4. BIP4 (Bahia); 5. CAP5 (Bahia); 6. LGP3 (Bahia); 7. PTP4 (Sergipe); 8. TCP2 (Sergipe) and 9. TCP6 (Sergipe).

When genetic information is obtained for poorly known species it permits researchers to select divergent genotypes, as well as to plan conservation strategies and allow the development of breeding programs [31]. The selection of highly divergent matrices and progenies in allogamous plants enables, through crosses between individuals, to maximize heterosis and increase the probability of higher segregation in future generations [32].

The mangaba tree has experienced major impact from human activity, compromising the survival of the species, which is part of a cultural socioeconomic context in the areas of occurrence. Research on the distribution and genetic composition is important to elaborate conservation and breeding strategies of the species, and the Mangaba Genebank is an example of it. In Sergipe, besides the genebank, there are 1232.30 hectares distributed in six private reserves, of which the RPPN of Caju is the largest, with 763.37 hectares, and is also located in Itaporanga d'Ajuda [33] As mangaba fruiting was recent in the genebank, occurring in the 2014-2015 harvest, our study was the first report on the progenies of this germplasm, which allowed a preliminary diagnosis of its genetic diversity and structure. This was the first analysis of genetic diversity with progenies of the Mangaba Genebank. The enrichment actions of this germplasm are constant and the results, although preliminary, will help to construct strategies of selection, crossing and facilitate new research.

\section{Conclusion}

This was the first survey ever conducted to characterize the genetic diversity of a mangaba progeny. The microsatellite markers revealed moderate genetic variability among the progenies and matrices of the accessions, according to the Fst divergence index. The progenies of accessions ABP1 and ABP2 (Pará) are the most divergent from the others and can be indicated for introduction in the BAGMangaba Genebank.

\section{Acknowledgements}

We thank the Conselho Nacional de Desenvolvimento Científico e Tecnológico 
(CNPq) for finnancial support of MCTI/CNPQ/Universal 14/2014 (process 9461020/2014-9) and SWE (203542/2014-2); the Laboratory of Molecular Systematic and Evolutionary Genetics/University of Florida (DSc. Douglas Soltis and DSc. Pamela Soltis) for providing SOARES, A.N.R. with an internship; and Embrapa Coastal Tablelands for supporting this project.

\section{References}

[1] Silva, A.V.C., Santos, A.R.F., Wickert, E., Costa, T.S. and Silva Júnior, J.F. (2011) Genetic Diversity between Hancornia speciosa Gomes Varieties. Revista Brasileira de Ciências Agrárias - Agrária, 6, 572-578. https://doi.org/10.5039/agraria.v6i4a943

[2] Costa, T.S., Silva, A.V.C., Ledo, A.S.L., Santos, A.R.F. and Silva Júnior, J.F. (2011) Genetic Diversity of Accessions of the Mangaba Germplasm Bank in Sergipe, Pesquisa Agropecuária Brasileira, 46, 499-508. https://doi.org/10.1590/S0100-204X2011000500007

[3] Arruda, A.S., Faria, R.Q., Peixoto, N., Moreira, A.S.F.P., Floriano, J.F., Graeff, C.E.O., Gonçalves, P.J. and Almeida, L.M. (2016) Mangabeira Latex Production Evaluation in Cerrado Region from Goiás. Ciência Florestal, 26, 939-948. https://doi.org/10.5902/1980509824222

[4] Silva, A.V.C., Soares, A.N.R., Ledo, A.S., Costa, T.S., Almeida, C.S., Amorim, J.A.E., Santos, P.S. and Vitoria, M.F. (2017a) Uses and Technological Prospects for the Mangaba, A Native Fruit of Brazil. African Journal of Biotechnology, 16, 302-311. https://doi.org/10.5897/AJB2016.15786

[5] Freitas, M.K.C., Coimbra, R.R., Aguiar, G.B., Aguiar, C.B.N., Chagas, D.B., Ferreira, W.M. and Oliveira, R.J. (2012) Phenotypic Variability and Morphologic Characterization of a Natural Population of Hancornia speciosa Gomes. Bioscience Journal, 28, 833-841.

[6] Jimenez, H.J., Martins, L.S., Montarrovos, A.V., Silva Júnior, J.F., Alzate-Marin, A.L. and Moraes Filho, R.M. (2015) Genetic Diversity of the Neotropical Tree Hancornia speciosa Gomes in Natural Populations in Northeastern Brazil. Genetics and Molecular Research, 14, 17749-17757. https://doi.org/10.4238/2015.December.21.48

[7] Silva, A.V.C., Amorim, J.A.E., Melo, M.F.V., Ledo, A.S. and Rabbani, A.R.C. (2017b) Genetic Diversity of Remaining Populations of Mangaba (Hancornia speciosa Gomes) in Restingas of Brazil. Journal of Agricultural Science, 9, 46-52.

[8] Soares, A.N.R., Vitoria, M.F., Nascimento, A.L.S., Ledo, A.S., Rabbani, A.R.C. and Silva, A.V.C. (2016) Genetic Diversity in Natural Populations of Mangaba in Sergipe, the Largest Producer State in Brazil. Genetics and Molecular Research, 15, 1503-8624. https://doi.org/10.4238/gmr.15038624

[9] Soares, F.S., Rossi, A.A.B., Silva, B.M., Cochev, J.S., Paiva Sobrinho, S. and Luz, P.B. (2017) Diversity and Genetic Structure of Mangabeira (Hancornia speciosa Gomes), a Fruit Species from Cerrado. Semina: Ciências Agrárias, 38, 2479-2488. https://doi.org/10.5433/1679-0359.2017v38n4SUPLp2479

[10] Amorim, J.A.E., Mata, L.R., Ledo, A.S., Azevedo, V.C.R. and Silva, A.V.C. (2015) Diversity and Genetic Structure of Mangaba Remnants in States of Northeastern Brazil. Genetics and Molecular Research, 14, 823-833. https://doi.org/10.4238/2015.February.2.7

[11] Ganga, R.M.D., Chaves, L.J. and Naves, R.V. (2009) Genetic Parameters in Hancornia speciosa Gomes Progenies from Cerrado. Scientia Forestalis, 37, 395-404.

[12] Kölliker, R., Rosellini, D. and Wang, Z. (2010) Development and Application of 
Biotechnological and Molecular Genetic Tools. In: Boller, B., Posselt, U.K. and Veronesi, F., Eds., Fodder Crops and Amenity Grasses, Springer Science, New York, 89-113. https://doi.org/10.1007/978-1-4419-0760-8_4

[13] Rodriguez-Rodriguez, M.P., Lopera-Barrero, N.M., Ribeiro, R.P., Povh, J.A., Vargas, L., Sirol, R.N. and Jacometo, C.B. (2010) Genetic Diversity of Piracanjuba Used in Stock Enhancement Programs with Microsatellite Markers. Pesquisa Agropecuária Brasileira, 45, 56-63. https://doi.org/10.1590/S0100-204X2010000100008

[14] Silva, A.V.C., Silva Júnior, J.F., Moura, C.F.H., Ledo, A.S., Menezes, D.N.B., Vitoria, M.F. and Amorim, J.A.E. (2015) Atributos de Qualidade de Funcionais de Acessos do Banco Ativo de Germoplasma de Mangaba da Embrapa Tabuleiros Costeiros. Embrapa Tabuleiros Costeiros, (Circular Técnica).

https://www.infoteca.cnptia.embrapa.br/infoteca/bitstream/doc/1041714/1/CT71.pd $\mathrm{f}$

[15] Doyle, J.J. and Doyle, J.L. (1990) Isolation of Plant DNA from Fresh Tissue. Focus, $12,13-15$

[16] Alzate-Marin, A.L., Guidugli, M.C., Soriani, H.H., Martinez, C.A. and Mestriner, M.A. (2009) An Efficient and Rapid DNA Minipreparation Procedure Suitable for PCR/SSR and RAPD Analyses in Tropical Forest Tree Species. Brazilian Archives of Biology and Technology, 52, 1217-1224. https://doi.org/10.1590/S1516-89132009000500020

[17] Rodrigues, A.J.L., Yamaguishi, A.T., Chaves, L.J., Coelho, A.S.G., Lima, J.S. and Telles, M.P. (2015) Development of Microsatellite Markers for Hancornia speciosa Gomes (Apocynaceae). Genetics and Molecular Research, 14, 7274-7278. https://doi.org/10.4238/2015.July.3.2

[18] Hurlbert, S.H. (1971) The Nonconcept of Species Diversity: A Critique and Alternative Parameters. Ecology, 52, 577-586. https://doi.org/10.2307/1934145

[19] El Mousadik, A. and Petit, R.J. (1996) High Level of Genetic Differentiation for Allelic Richness among Populations of the Argan Tree [Argania spinosa (L.) Skeels] Endemic to Morocco. Theoretical and Applied Genetics, 92, 832-839. https://doi.org/10.1007/BF00221895

[20] Goudet, J. (1995) FSTAT (Version 1.2): A Computer Program to Calculate F-Statistics. Journal of Heredity, 86, 485-486. https://doi.org/10.1093/oxfordjournals.jhered.a111627

[21] Nei, M. (1977) F-Statistics and Analysis of Gene Diversity in Subdivided Populations. Annals of Human Genetics, 41, 225-233. https://doi.org/10.1111/j.1469-1809.1977.tb01918.x

[22] Peakall, R. and Smouse, P.E. (2006) GENALEX 6: Genetic Analysis in Excel. Population Genetic Software for Teaching and Research. Molecular Ecology, 6, 288-295. https://doi.org/10.1111/j.1471-8286.2005.01155.x

[23] Vazquez, A.I., Bates, D.M., Rosa, G.J.M., Gianola, D. and Weigel, K.A. (2014) Technical Note: An R Package for Fitting Generalized Linear Mixed Models in Animal Breeding. Journal of Animal Science, 88, 497-504. https://doi.org/10.2527/jas.2009-1952

[24] R Core Team (2017) R: A Language and Environment for Statistical Computing. R Foundation for Statistical Computing. https://www.R-project.org/

[25] Pritchard, J.K., Stephens, M. and Donnelly, P. (2000) Inference of Population Structure Using Multilocus Genotype Data. Genetics, 155, 945-959.

[26] Santos, K.L., Ducroquet, J.P.H.J. and Nodari, R.O. (2011) Genetic Characterization 
of Natural Populations of Pineapple Guava (Acca sellowiana) with Heterologous Microsatellites Markers. Biotemas, 24, 75-83.

[27] Martins, G.V., Martins, L.S.S., Veasey, E.A., Lederman, I.E. and Silva, E.F. (2012) Diversity and Genetic Structure in Natural Populations of Hancornia speciosa var. Speciosa Gomes in Northeastern Brazil. Revista Brasileira de Fruticultura, 34, 1143-1153. https://doi.org/10.1590/S0100-29452012000400023

[28] Costa, C.F., Collevatti, R.G., Chaves, L.J., Lima, J.S., Soares, T.N. and Telles, M.P.C. (2017) Genetic Diversity and Fine-Scale Genetic Structure in Hancornia speciosa Gomes (Apocynaceae). Biochemical Systematics and Ecology, 72, 63-67. https://doi.org/10.1016/j.bse.2017.03.001

[29] Rojas, S. and Clement Ch, Y. (2011) Genetic Diversity of the INPA Germoplasm Bank of Camu-Camu (Myrciaria dubia [H.B.K.] McVaugh) Using Microsatellites Markers (EST-SSR). Revista Corpoica-Ciencia y Tecnologia Agropecuaria, 12, 51-64. https://doi.org/10.21930/rcta.vol12_num1_art:215

[30] Wright, S. (1969) Evolution and the Genetics of Populations: The Theory of Gene Frequencies. University of Chicago Press, London, $520 \mathrm{p}$.

[31] Santana, I.B.B., Oliveira, E.J., Soares Filho, W.S., Ritzinger, R., Amorim, E.P., Costa, M.A.P. and Moreira, F.C. (2011) Genetic Variability among Umbu-Cajazeira Accessions by ISSR Markers. Revista Brasileira de Fruticultura, 33, 868-876.

https://doi.org/10.1590/S0100-29452011005000090

[32] Negreiros, J.R.S., Alexandre, R.S., Álvares, V.S., Bruckner, C.H. and Cruz, C.D. (2008) Genetic Divergence among Yellow Passion Fruit Progenies Based on Seed Traits. Revista Brasileira de Fruticultura, 30, 197-201. https://doi.org/10.1590/S0100-29452008000100036

[33] ICMBIO (Instituto Chico Mendes MMA) (2016) Reservas particulares do patrimônio natural, RPPN, Sergipe. ICMBIO.

http://sistemas.icmbio.gov.br/simrppn/publico/detalhe/763/ 